\title{
Overview of the Australian Commonwealth Administrative Law System: Preliminary Issues for Consideration
}

\author{
Francisco Esparraga \\ School of Law, University of Notre Dame Australia, Sydney, Australia \\ Email: francisco.esparraga@nd.edu.au
}

Received 18 November 2013; revised 19 December 2013; accepted 15 January 2014

Copyright (C) 2014 by author and Scientific Research Publishing Inc. This work is licensed under the Creative Commons Attribution International License (CC BY). http://creativecommons.org/licenses/by/4.0/ (c) (i) Open Access

\begin{abstract}
Administrative law is the body of law which provides the mechanisms for challenging and regulating government decision making. There are two fundamental elements in Australian administrative law-judicial review and merits review. Judicial review is concerned with the legality of administrative decisions, and is the sole province of the courts. Merits review is concerned with the substance of a decision and is carried out by various review bodies. Reasons for decisions lie at the heart of administrative decision-making. A statement of reasons should provide fairness by enabling decisions to be properly explained and defended and will assist the person affected by a decision to decide whether to exercise rights of review or appeal. Australian law does not yet recognize a general duty to give reasons for administrative decisions. However, there are legislative provisions which encapsulate an obligation to provide reasons. It is all part and parcel of procedural fairness-Findings on Material Questions of Fact; Reference to Evidence on which Findings of Fact are Based; Dealing with Inadequate Statements of Reasons; Requests for Further and Better Particulars.
\end{abstract}

\section{Keywords}

Australian Administrative Law; Merits and Judicial Review; Reasons for Decisions

\section{Brief Introduction}

Australia, as a former British colony, inherited the legal system of England. Until the middle of the 1970s, the Australian system of administrative law was very much like the system in England. Most administrative decisions were taken within government Departments. Some administrative decisions were capable of being re- 
viewed by specialist tribunals, particularly where rights of individuals were involved. Some decisions were only able to be challenged through the courts. Over many years the courts had established a set of criteria which were applied to test whether an administrative decision was affected by error of law.

Overall, Australian citizens had no realistic or affordable means to challenge administrative actions or decisions. Access to redress via the courts, through a judicial review process, was marked by rigidity and the inherent danger that justice could be denied by a technicality. The system was time consuming and often expensive.

Administrative decision-making in the modern State has grown exponentially since the 1970s and is often very complex. Most citizens are subject to a number of administrative decisions each year. One thinks of taxation assessments, social security decisions, licensing, educational and health matters, immigration and the like. Those in Government in Australia began thinking about whether final decision-making on administrative matters affecting private rights should appropriately be made in secret, without reasons, and without opportunity for review on the merits.

The Australian Government set up a number of Committees to consider the existing mechanisms for review of administrative decisions. ${ }^{1}$ The landmark reports of these Committees became a blueprint for a new approach to administrative decision-making in Australia at the Commonwealth level. It would eventually be copied at the State level.

One of the most significant recommendations of these Committees was that there should be a general tribunal with power to reconsider afresh most Commonwealth administrative decisions. The recommendation was for reconsideration of the merits. The newly created tribunal would be able to choose freely between all the decisionmaking options available to the original decision-maker and exercise all the discretions conferred on that decision-maker.

The recommendations of the Committee ultimately led to the establishment of four acts of the Commonwealth Parliament. They were the Administrative Appeals Tribunal Act 1975, the Federal Court of Australia Act 1976, the Ombudsman Act 1976 and the Administrative Decisions (Judicial Review) Act 1977.

In the 1980s, the reform agenda for Administrative Law broadened to incorporate government accountability to citizens: public disclosure of government documents and the control of government information handling. This was demonstrated by the introduction of the Freedom of Information Act 1982 and the Privacy Act 1988.

The 1990s would see the development of customer service charters and additional complaints handling procedures within government agencies and the growth of outsourced bodies delivering government services (Esparraga \& Ellis-Jones, 2011).

\section{What Is Administrative Law}

Administrative law is the body of law which provides the mechanisms for challenging and regulating government decision making. ${ }^{2}$ According to the Australian Administrative Law Policy Guide ${ }^{3}$, it is an accountability mechanism that applies to government decision making and provides for;

- decision making that is fair, high quality, efficient and effective

- individual access to review of both the merits and lawfulness of decisions and conduct

- accountability for government decisions and conduct, and

- public access to information about government decisions and processes, and individual access to personal information held by the government.

In short, it is a system underpinned by three broad principles:

1) Administrative Justice, which at its core is a philosophy that in administrative decision making, the rights and interests of individuals should be properly safeguarded;

2) Executive Accountability, which is the aim of ensuring that those who exercise the executive or coercive

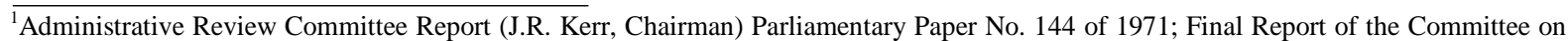
Administrative Discretions (Sir Henry Bland, Chairman); Parliamentary Paper No. 317 of 1973; Prerogative Writ Procedures: Report of Committee of Review (R.J. Ellicott, Chairman) Parliamentary Paper No. 53 of 1973. All the Committee Reports have been published in Robyn Creyke and John McMillan (eds), The Making of Commonwealth Administrative Law, 1996, Centre for International and Public Law. See also Robyn Creyke and John McMillan (eds), The Kerr Vision of Australian Administrative Law, 1998, Centre for International and Public Law.

${ }^{2}$ See Francisco Esparraga \& Ian Ellis-Jones, Administrative Law Guidebook, Oxford University Press, 2011; Mark Aronson \& Matthew Groves, Judicial Review of Administrative Action, $5^{\text {th }}$ Edition, Lawbook Co., 2013; Peter Cane \& Leighton McDonald, Principles of Administrative Law, $2^{\text {nd }}$ Edition, Oxford University Press, 2012.

${ }^{3}$ Approved by the Attorney-General, Commonwealth of Australia, 2012.
} 
powers of the State can be called on to explain and to justify the way in which they have gone about the task; and

3) Good Administration, which is the principle that administrative decision making should conform to universally accepted standards such as, rationality, fairness, consistency and transparency ${ }^{4}$ (McMillan, 2000).

Australian Commonwealth Administrative Law is based on the structural separation of powers flowing from Australia's Constitution:

- The Parliament is the legislative body which makes the laws and establishes the criteria for decision making and merits reviews of decisions;

- The Executive implements the laws through decision makers and merits review tribunals assessing the merits of particular cases; and

- The Judiciary declares and enforces the legal limits of the powers by undertaking judicial review.

\section{Administrative Law and Decision Making}

There are five core elements within the category of administrative law and decision making:

\subsection{Administrative Law Rules for Decision Makers}

1) Decision makers must act in accordance with the principles of natural justice, now referred to as "procedural fairness"

Natural justice imposes on decision makers a flexible obligation to adopt fair procedures that are appropriate and adapted to the circumstances of the particular case.

There are two main aspects of the concept of natural justice:

- The opportunity to be heard. A person should be given the opportunity to be heard before a decision that could adversely affect him or her in an individual way is made. This is called the "hearing rule".

- No bias. A decision maker must not be biased.

2) Decision makers must take account of relevant considerations and not take account of irrelevant considerations

3) Decisions must not be unreasonable

If a decision is so unreasonable that no reasonable person could have exercised their power in that way, the decision will be invalid.

4) Decision makers must not apply government policy inflexibly

A decision maker can take account of a relevant government policy in making a decision but must not apply that policy inflexibly and fail to take into account other relevant factors.

5) Decision makers must not act under dictation

If a decision involves the exercise of independent discretion, the decision maker must not act under dictation; that is, he or she must not act in accordance with the direction of another officer.

6) Decision makers must not act in bad faith

7) Decision makers must have legal authority to make a decision

8) There might be a duty to make enquiries before making a decision.

\subsection{The Decision and Reasons for the Decision}

Most Commonwealth agencies have a statutory obligation to provide a statement of reasons for a decision if requested to do so. Although there is no common law obligation to provide reasons for decisions, bodies such as the Administrative Review Council and the Commonwealth Ombudsman, and most agency service charters, counsel that it is good administrative practice to do so.

Legislation requires reasons to be provided in the following circumstances:

- where there is a right to merits review by the Administrative Appeals Tribunal

- where there is a right to judicial review by the Federal Court under the Administrative Decisions (Judicial Review) Act 1977. However, s. 13 of that Act excludes certain decisions from the requirement to give reasons - where the legislation under which the agency makes its decision requires it to give reasons when notifying

\footnotetext{
"4John McMillan, "Parliament and Administrative Law: The Vision in Hindsight-Parliament and the Constitution", Department of the Parliamentary Library, Research Paper No. 13, 2000.
} 
the person affected.

\subsection{Notification of Review Rights}

Although Commonwealth agencies are not generally obliged by common law to notify people of their review rights, some legislation does require this.

\subsection{Administrative Law Review Bodies, Mechanism and Remedies}

Decision makers should be aware that there are a number of ways in which their decisions can be reviewed. Different remedies are available, depending on the review process used.

There are nine core curriculum points associated with administrative law review bodies, mechanisms and remedies. Some of the review processes, however, might not be available for all decisions.

1) Judicial review by the Federal Circuit Court, the Federal Court, the High Court, and State and Territory courts exercising Federal jurisdiction

Judicial review, as will be detailed below, is where a court reviews a decision to make sure the decision maker used the correct legal reasoning or followed the correct legal procedures. The court does this by considering whether the decision is in accordance with the law. Judicial review can be carried out by the Federal Circuit Court, the Federal Court, the High Court, and by State and Territory courts exercising federal jurisdiction.

2) Merits review by administrative tribunals

Merits review, as will be detailed below, is where the reviewer has the capacity to "step into the shoes" of the primary decision maker and make the correct or preferable decision according to the merits of the case in question.

3) Internal review by agencies

Many agencies offer internal merits review of their administrative decisions. This process involves reviewing the merits of an officer's initial decision; the review is performed by another officer in the same agency, usually a more senior officer.

4) Investigation by the Ombudsman

The Ombudsman, to be discussed later, can investigate the administrative actions of Commonwealth government officials or agencies and can act in response to a complaint from a member of the public or on his or her own motion.

If the Ombudsman considers there has been defective administration, he or she can recommend that corrective action be taken. For example, it might be recommended that a particular decision be reconsidered, that an apology be provided, or that compensation be paid to the complainant.

5) Investigation by the Human Rights and Equal Opportunity Commission or bodies such as the independent Commission against Corruption

The Human Rights and Equal Opportunity Commission investigates and resolves by conciliation complaints about discrimination or breaches of human rights. This includes complaints made by members of the public about discriminatory decision making by government bodies. The NSW Independent Commission Against Corruption investigates corruption.

6) Other complaints avenues

There might be other government agencies a person can complain to about an administrative decision. For example, the Merit Protection Commissioner has a role in reviewing actions affecting Australian Public Service employees.

7) Alternative dispute resolution

It might also be possible for particular administrative activity to be the subject of alternative dispute-resolution processes such as conciliation or mediation.

8) Compensation

It might be possible to take legal action for damages to obtain compensation for loss suffered as a result of defective administration. Such action would generally be limited to circumstances in which a person can establish a breach of a duty to take reasonable care (for example, if incorrect advice is given by telephone), a breach of a contractual duty, a breach of the equitable duty of confidence or, if the decision can be characterised as occurring in the course of trade or commerce, misleading or deceptive conduct.

An action for damages against the Commonwealth would usually be heard by a State or Territory Supreme 
Court or, less commonly, by the Federal Court or the High Court.

There is also an administrative compensation scheme, the Compensation for Detriment Caused by Defective Administration Scheme, that enables Commonwealth agencies to compensate people who have suffered a loss as a result of the "defective" action or inaction of an agency and have no other avenue of redress; for example, the defective administration complained of does not amount to negligence. The scheme is monitored by the Commonwealth Ombudsman.

9) Standing to commence administrative law review

Only persons with "standing” have the right to bring an action for review of an administrative decision. A person has standing to seek judicial review if they are aggrieved by the decision. Similarly, a person can seek merits review in the Administrative Appeals Tribunal if their interests are affected by the decision.

\subsection{Information and Access}

1) Commonwealth agencies have responsibility for creating and maintaining accurate records of their business activities; this includes their decision-making functions. The freedom of information, privacy and archives obligations are undertaken through the Information Commissioner, the Freedom of Information Commissioner and the Privacy Commissioner ${ }^{5}$ (Administrative Review Council, 2011).

\subsection{Three Core Points Are Relevant Here}

1) Freedom of information obligations

The Freedom of Information Act 1982, Australian Information Commissioner Act 2010 and Freedom of Information Amendment (Reform) Act 2010 allow a person access to government documents. It requires that agencies publish information about their operations and their powers as they affect members of the public; they are also required to make public their manuals and other documents used in making decisions and recommendations affecting the public. Further, unless a document comes within an excepted or exempted category under some legislation, agencies must permit access to documents in their possession.

2) Privacy obligations

The Privacy Act 1988 provides protection for personal information handled by Commonwealth agencies. It covers collection, use and disclosure and the quality and security of personal information.

3) Archival obligations

The Archives Act 1983 prohibits the destruction, disposal or altering of Commonwealth records without permission from the National Archives of Australia. As a result of the operation of the Archives Act, Commonwealth agencies have responsibilities in relation to record keeping.

\section{The Distinction between Judicial Review and Merits Review}

There are two fundamental elements in Australian administrative law-judicial review and merits review. Judicial review is concerned with the legality of administrative decisions, and is the sole province of the courts. Merits review is concerned with the substance of a decision and is carried out by various review bodies. The distinction between judicial review and merits review is the consequence of the doctrine of the separation of powers, referred to above, which is enforced more strictly in Australia than in most other common law jurisdictions.

\subsection{Merits Review}

Review on the merits is concerned with whether a legally sound decision was the "correct and preferable" one. Merits review is the sole responsibility of the executive, because the person or tribunal conducting the review "stands in the shoes" of the original administrative decision-maker. Administrative tribunals are not bound by strict rules of evidence and seek to provide a less formal atmosphere than the courts. If the reviewing body would have made a different decision, then that decision will be substituted for the original decision.

In the Administrative Appeals Tribunal, for example, where jurisdiction is conferred, applications may be made to the Tribunal to review decisions. ${ }^{6}$ For the purpose of reviewing a decision, the Tribunal exercises all the

${ }_{5}^{5}$ See Administrative Review Council, Legal Training for Primary Decision Makers: A Curriculum Guideline, Attorney-General's Department, 2011.

${ }^{6}$ Administrative Appeals Tribunal Act 1975, (Cth), s 25(1). 
powers and discretions that are conferred by any relevant enactment on the person who made the decision. ${ }^{7}$ The Tribunal simply steps into the shoes of the original decision maker, reviews the decision and makes the decision which the administrator, in its opinion, ought to have made in the first place.

According to the Federal Court, the Administrative Appeals Tribunal has been given a jurisdiction which goes beyond that normally exercised by judges:

"The function of the Tribunal is... an administrative one. It is to review the administrative decision that is under attack before it. In that review, the Tribunal is not restricted to considerations which are relevant to a judicial determination of whether a discretionary power allowed by statute has been validly exercised. Except in a case where only one decision can be lawfully made, it is not ordinarily part of the function of a court either to determine what decision should be made in the exercise of an administrative discretion in a given case or, where a decision has been lawfully made in pursuance of a permissible policy, to adjudicate on the merits of the decision or the propriety of the policy. That is primarily an administrative rather than a judicial function. It is the function which has been entrusted to the Tribunal."8

Under these circumstances, the Tribunal began to explore ways of exercising its powers. Justice Brennan, the Tribunal's first President, posed four questions in the Tribunal's first deportation case. It was also the first reference to the test of what was "right or preferable":

"There are four related but distinct issues which may arise in any application to review a decision to order deportation under s 13(a) of the Migration Act 1958. First, is it a case where the Minister may order deportation under s 13(a)? Second, if the Minister has a policy which governs or affects the exercise of the power, is that policy consistent with the Act? Third, if the Minister has such a policy, is any cause shown why the Tribunal ought not to apply the policy either generally or in the particular case? And finally, on the facts of the case and having regard to any policy considerations which ought to be applied, is the Minister's decision the right or preferable one."9

These four questions provide the constant themes of merits review with the overriding duty being to reach the "correct or preferable" decision. This must be achieved with fairness and impartiality. Powers must only be exercised for the purposes for which they exist and by taking only relevant considerations into account and not taking irrelevant considerations into account.

In the end, the "correct or preferable" decision has been taken to mean that a Tribunal must make a decision that is correct in law but that, if a range of decisions could be made, all of which are correct in law, the Tribunal can choose the preferable decision. ${ }^{10}$ In short:

- correct - in the sense that they are made according to law; and

- preferable - in the sense that, if there is a range of decisions that are correct in law, the decision settled upon is the best that could have been made on the basis of the relevant facts.

Scope for making a preferable decision still exists when discretion is available in the exercise of the decision making power (Administrative Review Council, 1995).

In the more than 30 years since Drake was decided, the definition of the task that administrative tribunals must undertake remains unchanged. ${ }^{11}$ However, there have been significant changes in the nature of reviewable decisions. (Brennan 1996) In particular, discretionary powers have largely been removed from legislation conferring benefits or regulating activity including immigration and social welfare law.

\subsection{Judicial Review}

The classic exposition of the principle supporting judicial review can be found in the words of Justice Brennan in Ainsworth $v$ Criminal Justice Commission ${ }^{12}$ where he stated that Administrative Law "depends at base on the principle that any person who purports to exercise an authority conferred by a statute must act within the limits and in the manner which the statute prescribes". 
In an earlier case, ${ }^{13}$ Justice Brennan had described judicial review in the following terms:

"The duty and jurisdiction of the court to review administrative action do not go beyond the declaration and enforcing of the law which determines the limits and governs the exercise of the repository's power. If, in so doing, the court avoids administrative error or injustice, so be it; but the court has no jurisdiction simply to cure administrative injustice or error. The merits of administrative action, to the extent that they can be distinguished from legality, are for the repository of the relevant power and, subject to political control, for the repository alone."

It is a statement confirming that the role of the courts in judicial review is based on the principles of ultra vires and precludes merits review. Judicial review is concerned only with the legality of administrative decisions. Judicial review is not concerned with the general merits of administrative decisions under review (Aronson, Dyer, \& Groves, 2004). In short, “all power has its limits” (Aronson, Dyer, \& Groves, 2004; Preston, 2006) ${ }^{14}$ and when administrative decision makers act outside their limits, they may be restrained by the courts.

In a later case, Justice Brennan would describe the concept as follows:

"Judicial review is neither more nor less than the enforcement of the rule of law over executive action; it is the means by which executive action is prevented from exceeding the powers and functions assigned to the executive by law and the interests of the individual are protected accordingly."15

Judicial review will not prevent wrong decisions, but it may prevent them from being made unjustly. It does not matter whether the judge who is reviewing the decision would him or herself have arrived at a different conclusion to the administrative decision-maker. The decision will only be interfered with if there was some illegality in the process by which it was made. The jurisdiction of the court will be confined to quashing the decision and remitting the matter back to the original decision maker for determination in accordance with the law.

As Justice McClellan has more recently stated:

"This may not always be satisfying either for individual judges or for the party seeking relief but it is often the unfairness in the making of a decision, rather than the decision itself, that causes people the greatest distress."16

In order to make judicial review more accessible, the Administrative Decisions (Judicial Review) Act (Cth) (ADJR Act) was enacted in 1977. This statute provides a coherent structure for judicial review:

- the Act specifies who can commence proceedings (s 3(4)), how the proceeding are to be commenced (s 11) and when a third party can join an ADJR proceeding (s 12);

- it defines the range of Commonwealth decisions and actions that are reviewable under the Act (s 3), and the decisions excluded from review (s 3(1), Schedule 1);

- it lists 18 grounds on which decisions and conduct can be set aside by a court (ss 5, 6);

- it sets out the relief that can be granted by a court when a breach of a ground of review is established (s 16); and

- it assists a person to obtain a written statement of reasons for a decision prior to commencing proceedings (s 13).

In addition to codifying the common law grounds of review, the ADJR Act ensures that reasons can be obtained for almost any decision to which the Act applies (s 13). There is no equivalent common law duty for administrators to provide reasons for their decisions. With few exceptions, the grounds of review under the ADJR Act and the common law are the same.

Of particular importance are the grounds of judicial review provided in s 5 of the ADJR Act, which include:

- a breach of the rules of natural justice;

- a failure to observe the procedures that were required by law to be observed in connection with the making of the decision;

- the person who purported to make the decision did not have jurisdiction to make the decision;

- the decision was not authorized by the enactment in pursuance of which it was purported to be made;

- the making of the decision was an improper exercise of the power conferred by the enactment in pursuance of which it was purported to be made. An exercise of power may be improper if the relevant conduct involves:

- taking an irrelevant consideration into account in the exercise of a power;

- failing to take a relevant consideration into account in the exercise of a power;

\footnotetext{
${ }^{13}$ Attorney-General (NSW) v Quin (1990) 170 CLR 1 at 35-36.

${ }^{14}$ Mark Aronson, B Dyer and Mathew Groves, Judicial Review of Administrative Action, 3rd Ed, Law Book Co, 2004, p. 85; quoted in: B. J.

Preston, "Judicial review of illegality and irrationality of administrative decisions in Australia," Paper presented to the Joint Seminar on

Legality of Administrative Behaviours and Types of Adjudication, Xian, 11-13 April 2006.

${ }^{15}$ Church of Scientology $v$ Woodward (1982) 154 CLR 25 at 70.

${ }^{16}$ Paper presented to the International Symposium, Hangzhou, China, 31 October-4 November 2006.
} 
- an exercise of a power for a purpose other than a purpose for which the power is conferred;

- an exercise of a discretionary power in bad faith;

- an exercise of a personal discretionary power at the direction or behest of another person;

- an exercise of a discretionary power in accordance with a rule or policy without regard to the merits of the particular case;

- an exercise of a power that is so unreasonable that no reasonable person could have so exercised the power;

- an exercise of a power in such a way that the result of the exercise of the power is uncertain; and

- any other exercise of a power in a way that constitutes abuse of the power;

- an error of law;

- the decision was induced or affected by fraud;

- there was no evidence or other material to justify the making of the decision, but only if:

- the person who made the decision was required by law to reach that decision only if a particular matter was established, and there was no evidence or other material (including facts of which he or she was entitled to take notice) from which he or she could reasonably be satisfied that the matter was established; or

- the person who made the decision based the decision on the existence of a particular fact, and that fact did not exist;

- the decision was otherwise contrary to law.

ADJR Act judicial review proceedings have dealt with numerous areas of administrative decision making including taxation, broadcasting, migration, customs, health services, aboriginal heritage protection, pharmaceutical regulation, and personnel decision making. ${ }^{17}$

Examples of leading cases decided under the ADJR Act include:

- Kioa $v$ West (1985) 159 CLR 550 on natural justice

- Sean Investments Pty Ltd v Mackellar (1981) 38 ALR 363 on the obligation to consider relevant matters

- Minister for Aboriginal Affairs v Peko-Wallsend Ltd (1986) 162 CLR 24 on the obligation to consider relevant matters

- Schlieske v Minister for Immigration and Ethnic Affairs (1988) 84 ALR 719 on unauthorised purpose

- Tickner v Chapman (1995) 133 ALR 226 on Ministerial decision making

- Curragh Queensland Mining Ltd v Daniel (1992) 34 FCR on the no evidence principle

- Mudginberri Station Pty Ltd v Langhorne (1985) 68 ALR 613 on the statutory duty to provide a service

- Wattmaster Alco Pty Ltd v Button (1986) 70 ALR 330 on judicial review remedies

- North Coast Environment Council Inc v Minister for Resources (1994) 55 FCR 492 on standing.

A number of these areas will be discussed later in this paper and subsequent papers.

\section{Reasons for Decisions}

\section{The Importance of Reasons for Decisions}

Lord Hewart in $R v$ Sussex Justices; Ex parte McCarthy [1924] 1 KB 256, stated:

"...it is not merely of some importance but is of fundamental importance, that justice should not only be done, but should manifestly and undoubtedly be seen to be done."18

This is often referred to as the principle of open justice. In short, that "justice must be seen to be done". In this paper, I use the word "justice" to mean fair outcomes arrived at by fair procedures. It influences many areas of our practice and procedure, including the obligation to give reasons.

The principle of open justice is reinforced by Australia's ratification of the International Covenant on Civil and Political Rights 1966 (ICCPR), Article 14 of which relevantly provides as follows:

" 1 . All persons shall be equal before the courts and tribunals. In the determination of any criminal charge against him, or of his rights and obligations in a suit at law, everyone shall be entitled to a fair and public hearing by a competent, independent and impartial tribunal established by law. The Press and the public may be excluded from all or part of a trial for reasons of morals, public order (ordre public) or national security in a democratic society, or when the interests of private lives of parties so requires, or to the extent strictly necessary in the opinion of the court in special circumstances where publicity would prejudice the interests of justice; but

\footnotetext{
${ }^{17}$ See Professor John McMillan, Australian Information Commissioner, “Restoring the ADJR Act in Federal Judicial Review”, Presentation to the AIAL Seminar, Canberra, 4 December 2012.

${ }^{18}$ At 259.
} 
any judgment rendered in a criminal case or in a suit at law shall be made public except where the interest of juvenile persons otherwise requires or the proceedings concern matrimonial disputes or the guardianship of children." [Emphasis added]

Australia is a party to the Covenant. It is also scheduled and annexed to the Human Rights and Equal Opportunity Commission Act 1986 (Cth). As such, the Covenant is not made a part of Australian law. However, this method of "quasi-incorporation" of international human rights instruments, with their national reporting requirements and forums, established for the discussion of those reports, renders the Covenant a powerful influence on Australian courts and tribunals.

Sir Gerard Brennan emphasized in the case of Mabo:

"The common law does not necessarily conform with international law, but international law is a legitimate and important influence on the development of the common law, especially when international law declares the existence of universal human rights." ${ }^{19}$

More recently, Justice Spigelman, former Chief Justice of the NSW Court of Appeal stated in 1999:

“...the principle of open justice as one of the most fundamental rules of our legal system." 20

It is sometimes said that the most important person at a hearing is the person who is going to lose. Reasons for decision are of greater significance to that person than the party who wins.

The party who wins, usually has a strong conviction in the correctness of his or her position. When the decision-maker agrees, the decision-maker is not telling the winning party anything he or she does not know.

It is the person who loses, the one who misses out, the one who is rejected, who will be anxious to know why he or she has not been successful.

What do we mean when we talk about judgment writing or decision writing or giving reasons for decisions? All courts and tribunals conclude their activity with a formal pronouncement of the result in the proceeding.

In a court it is called a judgment. In a tribunal it is called a decision or reasons for a decision.

The word "reasons" is very important in that phrase. The document accompanying the formal order or finding or judgment is a document which in our system is intended to expose the process of reasoning that has lead the court or tribunal or decision-maker to come to the conclusion at which it has arrived. As to the determination of each issue in the case, the reasons should ask the question "why?".

A statement of reasons should provide fairness by enabling decisions to be properly explained and defended and will assist the person affected by a decision to decide whether to exercise rights of review or appeal. It is difficult if not near impossible, to bring an action for judicial review if a person affected by a decision does not know how or why a decision was reached. Any failure to explain the basis of a decision can mean that the person affected by the decision is left with the real grievance that they were not told why the decision was made. ${ }^{21}$

In the Second Reading Speech introducing the Administrative Decisions (Judicial Review) Act (Cth) 1977, the then Attorney-General, the Hon R J Ellicott QC, explained:

"... a person who is aggrieved by a decision usually has no means of compelling the decision-maker to give his reasons for the decision or to set out the facts on which the decision is based. Lack of knowledge on these matters will often make it difficult to mount an effective challenge to an administrative decision even though there may be grounds on which that decision can be challenged in law. Accordingly, one of the principal elements of the present Bill is a provision that will require a decision-maker to give to a person who is adversely affected by his decision the reasons for that decision and a statement of findings on material questions of fact, including the evidence or other material on which those findings were based..."22 (Administrative Review Council, 2007).

It may also mean that the person affected is persuaded by the statement of reasons, not to proceed. In other words, there is clear justification for the decision. In the words of Justice Woodward, it may enable the person affected to say:

"Even though I may not agree with it, I now understand why the decision went against me. I am now in a position to decide whether that decision has involved an unwarranted finding of fact, or an error of law, which is worth challenging.,"23

\footnotetext{
${ }^{19}$ Mabo v Queensland (No2) (1992) 175 CLR 1 at 42.

${ }^{20}$ Justice Spigelman, “Seen to be Done: The Principle of Open Justice”, Keynote Address to the $31^{\text {st }}$ Australian Legal Convention, Canberra, 9 October 1999.

${ }^{21}$ See Justice Megaw in Re Poyser and Mills’ Administration [1964] 467 and Dornan v Riordan (1990) 24 FCR 564.

${ }^{22}$ Second Reading Speech of the Administrative Decisions (Judicial Review) Bill 1977, Parliamentary Debates, 30th Parliament, 2nd Session at 1394-96 on 28 April 1977. See also Administrative Review Council, “Decision Making: Reasons”, Best Practice Guide 4, August 2007.

${ }^{23}$ Ansett Transport Industries (Operations) Pty Ltd v Wraith (1983) 48 ALR 500 at 507.
} 
It may also assist in determining whether the person affected has standing to challenge the decision.

Statements of reasons can also improve the quality of decision making. In particular, the possibility of disclosure of the decision-making process may encourage decision-makers to reflect more carefully on their task, and facilitate intra-agency quality assurance processes. ${ }^{24} \mathrm{~A}$ statement of bare conclusions without adequate reasons may leave the decision maker open to the suggestion that the matter has not been given sufficient attention or that extraneous matters have been allowed to affect the decision.

The availability of reasons can also benefit the wider community by providing examples of how the law is applied to particular fact situations. ${ }^{25}$ Justice Sheppard in the Pharmacy Guild case ${ }^{26}$ commented that a prime purpose for providing a statement of reasons is the disclosure of the reasoning process to the public and the parties. As such, it engenders confidence in the community that the decision maker has undertaken the task of decision making in a fair and appropriate manner.

Reasons for decisions can also assist tribunals and courts in identifying whether the decision maker erred in law, by revealing the factual material on which the decision was made, the considerations taken into account and the processes taken by the decision maker. If there are procedural requirements that need to be demonstrated, these will be outlined in the statement of reasons.

Professors Robin Creyke and John McMillan have identified three types of arguments in support of providing reasons (Creyke \& McMillan, 2009). Firstly, so-called "instrumentalist arguments" maintain that "the requirement to provide reasons for decisions... encourages better and more rational decision making" ${ }^{27}$ (Administrative Review Council, 2012). Secondly:

"The requirement for administrative decision makers to provide reasons for their decisions is thought to enhance government transparency and accountability and give legitimacy to a decision by showing that the decision was not made arbitrarily and that issues raised by interested parties have been adequately considered." 28

Thirdly, the "more highly contested" group of arguments which might be called the procedural fairness arguments:

"are based on an individual rights model of administrative decision making and assert that, as a matter of fairness, there should be a duty to provide reasons for decisions so people affected can decide whether the decision has been lawfully made and why they have not succeeded; whether there are grounds for review or appeal; and to assess the strength of the case against them should they seek review or appeal."29

However, it should be kept in mind that Government decision makers make a broad range of decisions and it is impossible to provide one overriding approach on an obligation to give reasons.

\section{Is There an Obligation to Provide Reasons for Decisions?}

Australian law does not yet recognize a general duty to give reasons for administrative decisions. Consequently, it is always necessary to consider the particular statutory scheme in question in order to ascertain whether reasons must be given. Whether fairness requires that reasons be given will depend on the circumstances of the case $^{30}$ (Taggart, 1986). The infamous case of Osmond from where this principle emanates, does not sit well with the general culture of justifying reasons for decisions. ${ }^{31}$ Chief Justice Gibbs expressed the general principle as follows:

"There is no general rule of the common law, or principle of natural justice, that requires reasons to be given for administrative decisions, even decisions which have been made in the exercise of statutory discretion and which may adversely affect the interests, or defeat the legitimate or reasonable expectations, of other persons., 32

It needs to be noted that there are three qualifications on the common law positions. Firstly, the principles of

\footnotetext{
${ }^{24}$ Commonwealth of Australia v Pharmacy Guild of Australia (1989) 91 ALR 65.

${ }^{25} \mathrm{H}$ Katzen, "Inadequacy of Reasons as a Ground of Appeal”, (1993) 1 Australian Journal of Administrative Law 33 at 36.

${ }^{26}$ Op cit Commonwealth of Australia v Pharmacy Guild of Australia (1989) 91 ALR 65.

${ }^{27}$ Robin Creyke and John McMillan, Control of Government Action: Text, Cases and Commentary, LexisNexis $2^{\text {nd }}$ ed, 2009 at 1261 . Also referred to in Administrative Review Council, Federal Judicial Review in Australia, Report No. 50, September 2012, at 154.

${ }^{28}$ Ibid.

${ }^{29}$ Ibid.

${ }^{30}$ See Public Service Board of NSW v Osmond (1986) 159 CLR 656; Michael Taggart, “Osmond Judicial Review of Administrative Action in the 1980s-Problems and Prospects", OUP, Auckland, 1986,

${ }^{31}$ Peter Cane \& Leighton McDonald, Cases and Materials for Principles of Administrative Law, 2nd ed., Oxford University Press, 2013.

${ }^{32}$ Osmond op cit at 666.
} 
procedural fairness require a decision maker who is making a decision which may adversely affect a person to give that person notice of the reasons for the decision. ${ }^{33}$ The person who is affected is then provided with an opportunity to respond to the case against them.

Secondly, even if there is no formal requirement for reasons for a decision, there may be circumstances where the courts may infer that a decision maker who has not given reasons, had no good reason for such a decision. In this case, the decision may be reviewable as an error of law or on other grounds, such as a failure to take into account relevant considerations.

Thirdly, the Osmond case did leave open the possibility that in exceptional circumstances, the common law principles of procedural fairness may require the decision maker to give reasons. The Court did not identify what circumstances might give rise to such a requirement.

Most Commonwealth agencies have a statutory obligation to provide a statement of reasons for a decision if requested to do so. Although there is no common law obligation to provide reasons for decisions, bodies such as the Administrative Review Council and the Commonwealth Ombudsman, and most agency service charters, counsel that it is good administrative practice to do so.

In general terms, legislation requires reasons to be provided in the following circumstances:

- where there is a right to merits review by the Administrative Appeals Tribunal (AAT)

- where there is a right to judicial review by the Federal Court under the Administrative Decisions (Judicial Review) Act 1977. However, s. 13 of that Act excludes certain decisions from the requirement to give reasons

- where the legislation under which the agency makes its decision requires it to give reasons when notifying the person affected.

\section{A Right of Merits Review by the AAT}

Section 28(1) of the AAT Act, encapsulates the obligation to provide reasons where there is:

- a decision that is reviewable by the AAT, and

- a request for reasons made in writing by a person whose interests are adversely affected by the decision.

The AAT may only review decisions where it has been given jurisdiction to do so by an enactment. Such enactment will identify the person or persons whose decisions are subject to review. ${ }^{34}$ Applications for review may be made by or on behalf of a person whose interests are affected by those decisions. So too, an organisation or association may have interests affected. ${ }^{35}$

"Interests affected" may be non-material, for example, intellectual or spiritual interests. They may not be confined to property, financial or physical interests. However, "interests affected" need to be more than the interests of a person as a member of the general public and other than as a person holding a belief that a particular type of conduct should be prevented or a particular law observed. ${ }^{36}$

Section 28A(1) of the AAT Act, requires the decision maker to take such steps as are reasonably necessary to give any person whose interests are affected, notice of the making of the decision and the right to have that decision reviewed. Section 28 may also require the decision maker to notify the person affected of their right to request a statement of reasons, if such a statement has not been provided.

\section{A Right of Judicial Review by the Federal Court under the ADJR Act}

Section 13(1) of the ADJR Act, encapsulates the obligation to provide reasons where there is:

- a decision that is reviewable by the Federal Court, and

- a request for reasons made in writing by a person whose interests are adversely affected by the decision.

The decision maker may provide reasons in response to a request, even if there is doubt as to whether the decision is reviewable. A person is also entitled to request a statement of reasons even after proceedings to review a decision has been made. ${ }^{37}$ For a decision to be reviewable under the $A D J R$ Act, it must be:

- a decision of an administrative character; ${ }^{38}$

\footnotetext{
${ }^{33}$ See Barratt $v$ Howard [2000] FCA 190.

${ }^{34}$ AAT Act 1975 s 25.

${ }^{35}$ AAT Act 1975 s 27.

${ }^{36}$ Re Control Investments Pty Ltd and Australian Broadcasting Tribunal (No 1) (1980) 3 ALD 74 at 77-81.

${ }^{37}$ United Airlines v Department of Transport and Communication (1990) 26 FCR 598.

${ }^{38}$ Queensland Medial Laboratory v Blewett (1988) 84 ALR 615.
} 
- made under an enactment; ${ }^{39}$ and

- not a decision of the Governor-General or a decision listed in Schedule 1 to the ADJR Act. ${ }^{40}$

The type of "decision" that will be amenable to review under the ADJR Act has been considered in a number of cases. The leading case is Australian Broadcasting Tribunal $v$ Bond, ${ }^{41}$ in which the High Court described a decision reviewable under the ADJR Act as "generally... a decision which is final or operative and determinative, at least in a practical sense, of the issue of fact calling for consideration". ${ }^{2}$

Section 6 of the ADJR Act permits the review of "conduct" on the same grounds as review of a decision under s 5 . In Bond, the distinction between a decision and conduct was described by Chief Justice Mason in the following terms:

"The distinction between reviewable decisions and conduct engaged in for the purpose of making such a decision is somewhat elusive. However, once it is accepted that 'decision' connotes a determination for which provision is made by or under a statute, one that generally is substantive, final and operative, the place of 'conduct' in the statutory scheme of things becomes reasonably clear. In its setting in s.6 the word 'conduct' points to action taken, rather than a decision made, for the purpose of making a reviewable decision. In other words, the concept of conduct looks to the way in which the proceedings have been conducted, the conduct of the proceedings, rather than decisions made along the way with a view to the making of a final determination. Thus, conduct is essentially procedural and not substantive in character."43

As to decisions "of an administrative character", it is often difficult to distinguish between administrative, legislative and judicial functions. These issues were discussed in the Federal Court in Evans v Friemann ${ }^{44}$ and it applied a broad approach. Courts will usually strive to classify a decision as administrative in order to have jurisdiction.

Minister for Industry and Commerce v Tooheys $\mathrm{Ltd}^{45}$ was another major case where the Federal Court substantially modified the former rule for distinguishing between administrative and legislative power.

Under the Customs Act 1901 (Cth), the Minister had the power to make "by-laws" the effect of which was that goods attracted a lesser import duty. Tooheys sought review of a determination under that power but the Government argued that the decision was not of an administrative character. The court said that the designation of the decisions as "by-laws" did not necessarily mean that the power was legislative in nature. The issue had to be determined by their content and subject matter.

The court said that the Minister was applying the law in the exercise of his discretion to a particular set of circumstances. The court said that this did not mean that the Minister's decision was legislative in character. In effect, the court was widening the scope of "administrative character". An interesting opposite approach is taken by Justice Gummow in Queensland Medical Laboratory v Blewett ${ }^{46}$. In the end, it will come down to the court's interpretation of content and subject matter.

As to the final element "under an enactment", this is a particularly difficult area. ${ }^{47}$ The main case in the area is Griffith University v Tang ${ }^{48}$. In Griffith University v Tang, the High Court considered the meaning of the requirement that a decision be "made... under an enactment" before it is susceptible to judicial review. A majority of the Court held that the decisions of an assessment board and appeals committee at Griffith University did not meet this requirement.

Ms Tang was excluded from her PhD candidature program on the grounds that she had engaged in academic misconduct. After exhausting avenues of appeal within the university, she sought judicial review of the decision under s 20 of the Judicial Review Act 1991 (Qld), alleging breaches of natural justice, failures to comply with mandatory procedural requirements, improper exercises of power, and errors of law. The question before the Court was, however, whether the decisions of two sub-committees were made "under" the Griffith University Act 1998 (Qld) or any other enactment.

\footnotetext{
${ }^{39}$ Burns v Australian National University (1982) 40 ALR 707.

${ }^{40} A D(J R)$ Act 1977 s 3(1).

${ }^{41}(1990) 170$ CLR 321.

${ }^{42}$ Ibid 342.

${ }^{43}$ Ibid 342

${ }^{44}(1981) 35$ ALR 428

${ }^{45}(1982) 4$ ALD 661.

${ }^{46}(1988) 84$ ALR 615.

${ }^{47}$ See the differing decisions in ANU v Burns (1982) 64 FLR 166; Hamblin v Duffy (1981) 50 FLR 308; Neat Domestic Trading Pty Ltd v AWB Ltd (2003) 198 ALR 179.

${ }^{48}$ [2005] HCA 7.
} 
The University Act specified the functions of Griffith University, a body corporate, as including the provision of education at university standard, the encouragement of study and research, and the conferral of higher education awards. The University's governing body had the power to make statutes on matters including the admission, enrolment and disciplining of students and to make and notify university rules. Although nothing in the University Act specifically dealt with matters of admission to or exclusion from a research programme or any course of study [or] academic misconduct, there was no question of any committee acting ultra vires. The Higher Education (General Provisions) Act 1993 (Qld) had the effect of granting universities a monopoly on the conferral of higher education awards.

In a joint judgment Justices Gummow, Callinan and Heydon adopted a two-stage test for determining whether a decision was made under an enactment:

1) The decision must be expressly or implicitly required or authorized by the enactment.

2) The decision must itself confer, alter or otherwise affect legal rights or obligations, and in that sense it must derive from the enactment.

Although both criteria must be met, the decision need not affect existing rights or obligations: "it will be sufficient that the enactment requires or authorises decisions from which new rights or obligations arise". The right or obligations may derive from general law or statute.

In his dissenting judgment, Justice Kirby argued that the majority adopted "an unduly narrow approach to the availability of statutory judicial review directed to the deployment of public power". Emphasizing the "beneficial" nature of administrative review legislation, he argued:

"In elaborating the phrase 'made... under an enactment', courts should not strain themselves to adopt artificial interpretations in order to confine the text. The text itself provides for its own restrictions. Unnecessary restraints, without the clearest foundation in the statute, should not be introduced by judges."

\section{The Core Elements of Statements of Reasons}

A Statement of Reasons must contain the following:

- The decision

- The findings on material questions of fact

- The reference to the evidence or other material on which these findings were based; and

- The real reasons for the decision.

It is an explanation by the decision maker that will enable the applicant or to say:

"Even though I may not agree with it, I now understand why the decision went against me. I am now in a position to decide whether that decision has involved an unwarranted finding of fact, or an error of law, which is worth challenging., ${ }^{49}$

In Comcare v Parker, ${ }^{50}$ Justice Finn adopted the reasoning in Sun Alliance Insurance v Massoud ${ }^{51}$ when he said:

"The adequacy of the reasons will depend on the circumstances of the case. But the reasons will be inadequate if (a) the appeal court is unable to ascertain the reasoning upon which the decision is based; or (b) justice is not seen to have been done."

As one commentator has put it:

"What the parties, the court and the public want are the real reasons for a decision... stating the real reasons may well involve both honesty and courage.,52

In short, it is all part and parcel of procedural fairness (Robertson, 1996). However, the legal requirements as to the contents of statements of reasons will vary. The relevant legislation will outline any special requirements. Whatever its format, a statement of reasons must be a genuine statement of the actual reasons that were relied upon at the time the decision was made.

Section 13 of the Administrative Decisions (Judicial Review) Act 1977 is a standard template for a reasons statement:

Where a person makes a decision to which this section applies, any person who is entitled to make an application to the Federal Court or the Federal Magistrates Court under Section 5 in relation to the decision may, by notice in writing given to the person who made the decision, request him or her to furnish a statement in writing

\footnotetext{
${ }^{49}$ Justice Woodward in Ansett Transport Industries (Operations) Pty Ltd v Wraith (1983) 48 ALR 500 at 507.

${ }^{50}$ Federal Court of Australia, Justice Finn, 2 August 1996, Unreported.

${ }^{51}$ [1989] VR 8 at 18.

${ }^{52}$ A Robertson SC, “Writing Reasons for Decisions”, ARC Tribunal Conference 1996.
} 
setting out the findings on material questions of fact, referring to the evidence or other material on which those findings were based and giving the reasons for the decision.

\section{Findings on Material Questions of Fact}

A material fact is one on which the decision turns. The decision maker must state its findings on those questions of fact which the decision maker considers to be material to the decision which it makes and to the reasons it has in reaching that decision. ${ }^{53}$

Court decisions have considered what is meant by the requirements for decision makers to state their findings on material questions of fact. Some have regarded it as an objective test whilst others emphasize that it depends on what the decision maker considered to be material.

As an example, in Xu v Minister for Immigration and Multicultural Affairs, ${ }^{54}$ the court held that the legislation did not expressly or implicitly constrain the decision maker, the decision maker was the sole judge of what is material. This view was rejected in Minister for Immigration and Multicultural Affairs $v$ Singh, ${ }^{55}$ which held that the tribunal could not be the sole arbitrator of materiality because "the tribunal is under a duty to make, and to set out, findings on all matters of fact that are objectively material to the decision it is required to make."

The High Court in Minister for Immigration and Multicultural Affairs v Yusuf ${ }^{56}$ the majority rejected the view that "material" meant "objectively material" because this would impose a duty to make findings on facts in relation to a decision the tribunal was said to be notionally required to make, rather than the decision which was actually made.

This is not to mean that a decision maker has total control over what they can consider material and what they can dismiss. If a statement of reasons does not set out findings of fact on a particular matter, a reviewing court may infer that the decision maker did not consider that factual issue to be material and as such, it could be argued that the decision maker made an error of law or failed to take into account a relevant consideration.

The decision maker must also draw attention of the person affected by the decision to the relevant law, in order to enable that person to understand the legislative framework in which the decision was made. Similarly, a decision maker should avoid simply listing relevant cases by name and instead should explain the legal principles derived from the cases. ${ }^{57}$

\section{Reference to Evidence on Which Findings of Fact Are Based}

Any evidence or other material upon which the findings on material questions of fact are based must be referred to in the statement of reasons, as there needs to be some evidence for a finding of fact. This finding of fact must be based on logically probative evidence. If this is not the case, the parties may not be able to determine if the decision was based on speculation alone. ${ }^{58}$

A statement of reasons must be an exercise in judgment by a decision maker, where there is evidence of the decision maker balancing the available material and arriving at conclusions through logical thought processes. If there is material presented as evidence to the decision maker and it is relevant material to the decision, it must be referred to in the statement of reasons. If not, it can indicate that the decision maker has either failed to have regard to the relevant material or has made an error of law. ${ }^{59}$

Justice Sackville has stated that:

"It is not necessary that reasons address every issue raised in proceedings; it is enough that they deal with the substantial issues upon which the decision turns." 60

This being said, a statement of reasons must go further than stating the decision maker's conclusions. There must be a clear indication, preferably expressly, of how the reasoning process dealt with all the necessary considerations; linkages between facts and the decision and must also be able to be understood by the reader of the

\footnotetext{
${ }^{53}$ Minister for Immigration and Multicultural Affairs $v$ Yusuf (2001) 180 ALR 1 at paragraph 68.

${ }^{54}(1999) 168$ ALR 621.

${ }^{55}$ [2000] FCA 845.

${ }^{56}$ (2001) 180 ALR 1

${ }^{57}$ See Ansett Transport Industries (Operations) Ltd v Wraith (1983) 48 ALR 500; Anderson v Australian Postal Commission (1993) 32 ALD 138; McAuliffe v Secretary, Department of Social Security (1991) 13 AAR 462.

${ }^{58}$ Minister for Immigration and Ethnic Affairs v Pochi (1980) 44 FLR 41.

${ }^{59}$ See Minister for Immigration and Multicultural Affairs v Yusuf (2001) 180 ALR 1.

${ }^{60}$ Total Marine Services Pty v Kiely (1995) 51 ALD 635 at 640.
} 
statement of reasons. There also needs to be clear indications of possible appeal rights, either through internal review; specialist tribunals; generalist tribunals or judicial review.

Overall, a statement of reasons must contain three essential requirements: the findings on material questions of fact; reference to the evidence or other material on which those findings were based and the reasons for the decision.

\section{Dealing with Inadequate Statements of Reasons}

It is difficult to generalise about the standards which are applicable to all statements of reasons. Due to the variety of matters and the degrees of complexity in the decisions themselves, there is no single standard applicable, but rather, it is essential that a statement of reasons accurately reflects the true reasons.

Tribunals and courts which may have to review statements of reasons, have fashioned several ways by which to test the adequacy of statements of reasons. The Administrative Appeals Tribunal (AAT) for example, expressed it as follows:

"The reasons, when properly given, ensure that the citizen is sufficiently informed to determine whether he wishes to take the matter further, and if so, whether to make representations to the Minister, proceed in the appropriate court of law or seek review by this Tribunal." ${ }^{1}$

Justice Davies in the Federal Court case of Soldatow v Australia Council, ${ }^{62}$ said:

"Section 13(1) requires proper and adequate reasons which are intelligible, which deal with the substantial issues raised for determination and which expose the reasons process adopted. The reasons need not be lengthy unless the subject matter requires but they should be sufficient to enable it to be determined whether the decision was made for a proper purpose, whether the decision involved an error of law, whether the decision maker acted only on relevant considerations and whether the decision maker left any such consideration out of account.",63

So too, Justice Burchett in ARM Constructions Pty Ltd v Commissioner of Taxation ${ }^{64}$ stated:

"Section 13 is a crucial provision designed to ensure that the basis upon which a decision is made is able to be seen, so that its legality can be determined. It should not be viewed by any decision maker as a threat to be evaded by a camouflage of obscurity. All it requires to be set out is a statement of the matters the administrator must have considered in making the decision in the first place - what he found the facts to be, what material he considered in arriving at those findings, and the reasons for his ultimate decision."

It also needs to be noted that Section 25D of the Acts Interpretation Act 1901 (Cth) aims at insuring that adequate reasons are provided by decision makers who are required by Commonwealth statutes to provide them. In essence, Section 25D requires a decision maker to give reasons for a decision and those reasons should "set out the findings on material questions of fact and refer to the evidence or other material on which those findings were based."

\section{Requests for Further and Better Particulars}

If a statement of reasons is found not to be adequate, the person receiving the statement can apply to the Administrative Appeals Tribunal (AAT) under Section 28(1) of the Administrative Tribunal Act 1975, or to the Federal Court under Section 13(1) of the Administrative Decisions (Judicial Review) Act 1977.

If the Administrative Appeals Tribunal is of the view that the Statement of Reasons does not contain adequate findings on material questions of fact, an adequate reference to the evidence or other material on which those findings were based or adequate particulars of the reasons for the decision, the AAT will accordingly make such a declaration.

If this is the case, the decision maker must provide an additional statement containing further and better particulars in relation to the matters raised in the AAT's declaration. Such an additional statement must be provided within 28 days of the AAT's declaration.

Once again, if the AAT considers this statement to be inadequate, under section 37, the AAT can order the decision maker to provide another statement with further and better particulars.

Under section 13 of the $A D(J R) A c t$, the Federal Court also has the power to order the decision maker to provide

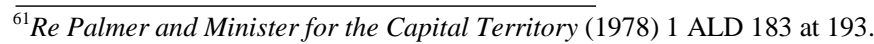

${ }^{62}$ (1991) 28 FCR 1 at 2.

${ }^{63}$ Ibid at 2.

${ }^{64}(1986)$ FCR 197 at 203.
} 
a statement of reasons. The federal Court must be satisfied that such a new statement of reasons would be useful.

The Federal Court can specify which matters in the statement of reasons require additional information or whether an entire new statement of reasons needs to be provided by the decision maker.

\section{Conclusion}

This paper, as the title suggested, has presented an initial overview of some of the leading issues being dealt within Australia's Administrative Law system.

It provides an introduction to Administrative Law and Decision Making and explains the distinction between Merits Review and Judicial Review. It focuses on Reasons for Decisions and the core elements of Statements of Reasons.

Each of these areas can be a focus of future papers in their own right.

It is hoped that this paper can provide an introductory taste for Australia's ever expanding Administrative Law system which faces major challenges with the growth of government and the expanding anti-terrorism legislation. These bring individual rights and public rights into sharp contrast and as such, Administrative Law must continue to offer legitimate safeguards.

\section{References}

Administrative Review Committee Report (J.R. Kerr, Chairman) Parliamentary Paper No. 144 of 1971; Final Report of the Committee on Administrative Discretions (Sir Henry Bland, Chairman); Parliamentary Paper No. 317 of 1973 ; Prerogative Writ Procedures: Report of Committee of Review (R.J. Ellicott, Chairman) Parliamentary Paper No. 53 of 1973.

Administrative Review Council (1995). Better Decisions: Review of Commonwealth Merits Review Tribunals. Report No. 39, Canberra: AGPS.

Administrative Review Council (2007). Decision Making: Reasons. Best Practice Guide 4, August.

Administrative Review Council (2011). Legal Training for Primary Decision Makers: A Curriculum Guideline. Canberra: Attorney-General's Department.

Administrative Review Council (2012). Federal Judicial Review in Australia, Report No. 50. September.

Aronson, M., Dyer, B., \& Groves, M. (2004). Judicial Review of Administrative Action (3rd ed.). Sydney: Law Book Co.

Aronson, M., \& Groves, M. (2013) Judicial Review of Administrative Action (5th ed.). Sydney: Lawbook Co.

Brennan, S. G. (1996) The AAT: Twenty Years Forward. The AAT 20th Anniversary Conference, 1-2 July 1996.

Cane, P., \& McDonald, L. (2013). Principles of Administrative Law (2nd ed.). Oxford: Oxford University Press.

Creyke, R., \& McMillan, J. (1996). The Making of Commonwealth Administrative Law. Canberra: Centre for International and Public Law.

Creyke, R., \& McMillan, J. (1998). The Kerr Vision of Australian Administrative Law. Canberra: Centre for International and Public Law.

Creyke, R., \& McMillan, J. (2009). Control of Government Action: Text, Cases and Commentary (2nd ed.). Dayton, OH: LexisNexis.

Esparraga, F., \& Ellis-Jones, I. (2011). Administrative Law Guidebook. Oxford: Oxford University Press.

Katzen, H. (1993). Inadequacy of Reasons as a Ground of Appeal. Australian Journal of Administrative Law, 33, 33-39.

McMillan, J. (2000). Parliament and Administrative Law: The Vision in Hindsight-Parliament and the Constitution. Research Paper No. 13, Canberra: Department of the Parliamentary Library.

McMillan, J. (2012). Restoring the ADJR Act in Federal Judicial Review. The AIAL Seminar, Canberra, 4 December 2012

Preston, B. J. (2006). Judicial Review of Illegality and Irrationality of Administrative Decisions in Australia. The Joint Seminar on Legality of Administrative Behaviours and Types of Adjudication, Xi'an, 11-13 April 2006.

Robertson, S. C. (1996). Writing Reasons for Decisions. ARC Tribunal Conference.

Spigelman, J. J. (1999). Seen to Be Done: The Principle of Open Justice. The 31st Australian Legal Convention, Canberra, 9 October 1999.

Taggart, M. (1986). Osmond Judicial Review of Administrative Action in the 1980s: Problems and Prospects. Auckland: OUP. 


\section{Cases}

Ainsworth v Criminal Justice Commission (1992) 175 CLR 564

Anderson v Australian Postal Commission (1993) 32 ALD 138

Ansett Transport Industries (Operations) Pty Ltd v Wraith (1983) 48 ALR 500

ANU v Burns (1982) 64 FLR 166

ARM Constructions Pty Ltd v Commissioner of Taxation (1986) FCR 197

Attorney-General (NSW) v Quin (1990) 170 CLR 1

Australian Broadcasting Tribunal v Bond (1990) 170 CLR 321

Barratt $v$ Howard [2000] FCA 190

Church of Scientology v Woodward (1982) 154 CLR 25

Comcare v Parker Federal Court of Australia, Justice Finn, 2 August 1996, Unreported

Commonwealth of Australia v Pharmacy Guild of Australia (1989) 91 ALR 65

Dornan v Riordan (1990) 24 FCR 564

Drake $v$ Minister for Immigration and Ethnic Affairs (1977) 24 ALR 577

Evans v Friemann (1981) 35 ALR 428

Griffith University v Tang [2005] HCA 7

Hamblin v Duffy (1981) 50 FLR 308

Kioa $v$ West (1985) 159 CLR 550

Mabo v Queensland (No 2) (1992) 175 CLR 1

McAuliffe v Secretary, Department of Social Security (1991) 13 AAR 462

Minister for Aboriginal Affairs v Peko-Wallsend Ltd (1986) 162 CLR 24

Minister for Immigration and Multicultural Affairs v Singh [2000] FCA 845

Minister for Immigration and Ethnic Affairs $v$ Pochi (1980) 44 FLR 41

Minister for Immigration and Multicultural Affairs v Yusuf (2001) 180 ALR 1

Minister for Industry and Commerce v Tooheys Ltd (1982) 4 ALD 661

Mudginberri Station Pty Ltd v Langhorne (1985) 68 ALR 613

Neat Domestic Trading Pty Ltd v AWB Ltd (2003) 198 ALR 179

North Coast Environment Council Inc v Minister for Resources (1994) 55 FCR 492

Public Service Board of NSW v Osmond (1986) 159 CLR 656

Queensland Medical Laboratory v Blewett (1988) 84 ALR 615

$R v$ Sussex Justices; Ex parte McCarthy [1924] 1 KB 256

Re Becker and Minister for Immigration and Ethnic Affairs (1977) 15 ALR 696

Re Control Investments Pty Ltd and Australian Broadcasting Tribunal (No 1) (1980) 3 ALD 74

Re Palmer and Minister for the Capital Territory (1978) 1 ALD 183

Sun Alliance Insurance v Massoud [1989] VR 8

Schlieske v Minister for Immigration and Ethnic Affairs (1988) 84 ALR 719

Sean Investments Pty Ltd v Mackellar (1981) 38 ALR 363

Soldatow v Australia Council (1991) 28 FCR 1

Tickner v Chapman (1995) 133 ALR 226

Total Marine Services Pty v Kiely (1995) 51 ALD 635

United Airlines v Department of Transport and Communication (1990) 26 FCR 598

Wattmaster Alco Pty Ltd v Button (1986) 70 ALR 330

Xu v Minister for Immigration and Multicultural Affairs (1999) 168 ALR 621

\section{Legislation}

Acts Interpretation Act 1901 (Cth)

Administrative Appeals Tribunal Act 1975 (Cth)

Administrative Decisions (Judicial Review) Act 1977 (Cth)

Federal Court of Australia Act 1976 (Cth)

Freedom of Information Act 1982 (Cth)

Griffith University Act 1998 (Qld) 
Higher Education (General Provisions) Act 1993 (Qld)

Human Rights and Equal Opportunity Commission Act 1986 (Cth)

Judicial Review Act 1991 (Qld)

Ombudsman Act 1976 (Cth)

Privacy Act 1988 (Cth) 